\title{
A review of perioperative anesthesia and analgesia for infants: updates and trends to watch [version 1; peer review: 2
}

\section{approved]}

\author{
Lizabeth D Martin, Nathalia Jimenez, Anne M Lynn (iD
}

University of Washington School of Medicine, Department of Anesthesiology \& Pain Medicine, Seattle Children's Hospital, Seattle, WA, USA

V1 First published: 08 Feb 2017, 6(F1000 Faculty Rev):120
https://doi.org/10.12688/f1000research.10272.1

Latest published: 08 Feb 2017, 6(F1000 Faculty Rev):120

https://doi.org/10.12688/f1000research.10272.1

\section{Abstract}

This review focuses on pharmacokinetics and pharmacodynamics of opioid and non-opioid analgesics in neonates and infants. The unique physiology of this population differs from that of adults and impacts drug handling. Morphine and remifentanil are described as examples of older versus recently developed opiates to compare and contrast pharmacokinetics and pharmacodynamics in infants. Exploration of genetics affecting both pharmacokinetics and pharmacodynamics of opiates is an area of active research, as is the investigation of a new class of mu-opiate-binding agents which seem selective for analgesic pathways while having less activity in pathways linked to side effects. The kinetics of acetaminophen and of ketorolac as examples of parenteral non-steroidal analgesics in infants are also discussed. The growth in regional anesthesia for peri-operative analgesia in infants can fill an important role minimizing intra-operative anesthetic exposure to opioids and transitioning to post-operative care. Use of multi-modal techniques is recommended to decrease undesirable opiate-related side effects in this vulnerable population.

\section{Keywords}

perioperative anesthesia and analgesia, neonatal and infant pharmacology, pharmacokinetics, pharmacodynamics,

\section{Open Peer Review \\ Approval Status \\ 1 2 \\ version 1 \\ 08 Feb 2017 \\ Faculty Reviews are review articles written by the prestigious Members of Faculty Opinions. The articles are commissioned and peer reviewed before publication to ensure that the final, published version is comprehensive and accessible. The reviewers who approved the final version are listed with their names and affiliations.}

\section{Sulpicio Soriano, Boston Children $\square \mathrm{s}$}

Hospital, Boston, USA

Harvard Medical School, Boston, USA

2. Souhayl Dahmani, Robert-Debré University Hospital, Paris, France

Paris Diderot University (Paris 7), Pres Paris

Sorbonne Cité, Paris, France

Any comments on the article can be found at the end of the article. 
Corresponding author: Lizabeth D Martin (lizabeth.martin@seattlechildrens.org)

Competing interests: The authors declare that they have no competing interests.

Grant information: The author(s) declared that no grants were involved in supporting this work.

Copyright: ( 2017 Martin LD et al. This is an open access article distributed under the terms of the Creative Commons Attribution License, which permits unrestricted use, distribution, and reproduction in any medium, provided the original work is properly cited.

How to cite this article: Martin LD, Jimenez $\mathrm{N}$ and Lynn AM. A review of perioperative anesthesia and analgesia for infants: updates and trends to watch [version 1; peer review: 2 approved] F1000Research 2017, 6(F1000 Faculty Rev):120

https://doi.org/10.12688/f1000research.10272.1

First published: 08 Feb 2017, 6(F1000 Faculty Rev):120 https://doi.org/10.12688/f1000research.10272.1 


\section{Introduction}

This article begins by highlighting the features of neonatal and infant physiology that differ from those of adults and impact drug handling. Definitions of pharmacokinetic terms and a brief introduction to models for drug metabolism will be presented. Morphine and remifentanil will be used as examples of older versus recently developed opiates to compare and contrast pharmacokinetics in infants. The pharmacodynamics of these agents is important to consider in this vulnerable group. Opioid-related side effects include respiratory depression, tolerance, ileus, urinary retention and pruritus. Genetics affecting both pharmacokinetics and pharmacodynamics of opiates has begun to be explored. The growth in regional anesthesia for peri-operative analgesia in infants can fill an important role, minimizing intra-operative anesthetic exposure and transitioning to post-operative care. Use of multi-modal techniques to decrease opiate-related side effects in vulnerable infants is also desirable. The kinetics of acetaminophen and of ketorolac (as examples of parenteral non-steroidal analgesics) in infants will be reviewed. Investigation of a new class of mu-opiate-binding agents, which seem selective for analgesic pathways while having less activity in pathways linked to side effects is a new area with clinical studies beginning in adults; this constitutes an important area to follow.

Clearly, the information to be presented will be our selection from the literature and cannot be a comprehensive review of all literature of these drugs or drug classes. References to some of the authors' own work is used for convenience and knowledge of study performance details, not to suggest that other work is not equally important.

\section{Physiology}

The physiology of the neonate and infant differs in many aspects from that of the adult; some of these differences are important factors for drug handling. Total body water is a higher percentage of body weight in infants, reaching adult values by the age of 8 to 10 years ${ }^{1}$. Liver and kidney function is not fully developed at birth, affecting handling of many drugs. The maturation of organ function occurs over several months during the first year of life. Drug development in the past 10 to 20 years has focused on agents whose metabolism is less dependent on normal renal or liver function (or both) since aging adults often have compromise in the function of these organs. This is beneficial for infants who also have immature function. Remifentanil is one obvious example of such a drug.

Hepatic enzymes, including both the P450 system and the glucuronidation pathways, are immature at birth. Maturation occurs over the first few months of postnatal life, at different rates for different P450 variants. The kidney is important for eliminating drugs or their metabolites. Drugs that are metabolized by glucuronidation (to increase solubility for excretion) will have delayed removal in the first months of life. Sulfation then becomes more important as a solubility pathway for urinary excretion. In infants, glomerular filtration rates start at approximately $10 \%$ of adult normal values, reaching these by 12 months of age. Renal tubular function also matures over the first 6 months. This immature function can result in the accumulation of metabolites and is particularly problematic when those metabolites have active effects.

\section{Pharmacokinetics}

Pharmacokinetics, clearance $(\mathrm{Cl})$, volume of distribution $(\mathrm{Vd})$, and elimination half-life ( $\mathrm{t} 1 / 2)$ are common pharmacologic terms, and familiarity can be helpful when reviewing this literature. Pharmacokinetics is defined as the study of drug disposition by patients; it is affected by absorption (important for non-intravenous [non-IV] routes of administration), distribution, metabolism, and elimination. Familiarity with common pharmacologic terms can be helpful when reviewing this literature ${ }^{2}$ and are briefly defined below since most readers are familiar with them.

$\mathrm{Cl}$ describes the removal of drug from a volume of plasma per unit of time $(\mathrm{mL} / \mathrm{min}, \mathrm{L} /$ hour or normalized as $\mathrm{mL} / \mathrm{min}$ per $\mathrm{kg}$, $\mathrm{L} /$ hour per $70 \mathrm{~kg})$.

Vd, another volume term, describes the apparent volume necessary to account for all drug if it were present at the same concentration as measured in plasma or serum $(\mathrm{L} / 70 \mathrm{~kg}$ or $\mathrm{mL} / \mathrm{kg})$. Importantly, $\mathrm{Vd}$ is a theoretical, rather than physiologic, volume. Its usefulness is to show how widely distributed a drug is in the body.

The $t \frac{1}{2}$ is the time needed to change blood concentration by $50 \%$ (minutes, hours). In 4 to 5 half-lives, $94 \%$ to $97 \%$ of drug is removed, respectively. Half-life is affected by both $\mathrm{Cl}$ and Vd. Drugs with a higher $\mathrm{Cl}$ and smaller $\mathrm{Vd}$ have a shorter duration of action and are more titratable, often desirable in anesthesia practice. As novel anesthetic drugs with these features have been developed, the term context-sensitive half-time has come into use. This term refers to the time to change drug concentration by $50 \%$ (that is, half-life) in the context of the duration of administration. Contextsensitive half-time pharmacokinetic models for IV anesthetic drugs have been described ${ }^{2,3}$. Many newer agents have been developed to achieve small context-sensitive half-times which are unchanged regardless of the duration of drug infusion.

Limitations on blood sampling volumes for pediatric patients, particularly significant in infants, have encouraged the development of computer-generated pharmacokinetic mathematical modeling schemes which use sparse blood concentration data from pediatric patients. Population-based models exist which use factors such as age and weight as regular covariates and introduce additional elements to improve the fit of the model in concentration versus time graphs. Weight-based allometric models incorporate weight by using exponential factors ( 0.75 for $\mathrm{Cl}$ and 1 for $\mathrm{Vd}$ ) based on enzyme function characteristics. These models consider ageappropriate factors such as creatinine or bilirubin to improve fit. Both models have been used to study morphine and remifentanil handling in infants ${ }^{4-8}$.

\section{Genetics influencing pharmacokinetics}

An active and rapidly evolving area of research is the study of genetic factors influencing pharmacokinetics and pharmacodynamics of analgesics. Although most studies involve animal models and the effect of genetic variants is sometimes difficult to extrapolate directly into clinical practice, there are examples of important metabolic-genetic variants pertinent to pediatric populations ${ }^{9}$. A prime example is codeine, a pro-drug that is entirely dependent on its metabolism for its analgesic effect. Its active metabolite, morphine, 
is produced by O-demethylation by the CYP2D6 (Cytochrome P450 2D6) enzyme, which is highly polymorphic. Differences in CYP2D6 alleles can result in significant differences in opiate effect because of variable CYP2D6 enzyme activity levels. Patients range from poor to ultra-rapid metabolizers on the basis of their combination of alleles. In clinical practice, patients who are poor metabolizers will not achieve any analgesia with codeine use, whereas patients who are ultra-rapid metabolizers have a higher risk of respiratory depression ${ }^{10-12}$. Similar concerns have been reported with tramadol, hydrocodone, and oxycodone, resulting in the publication of dosing guidelines considering CYP2D6 genotypes ${ }^{11,13,14}$.

The frequency of genetic polymorphisms varies between racial and ethnic populations. According to the previous example, European Caucasians are more likely to carry normal function CYP2D6 alleles compared with Asians and African-Americans ${ }^{15}$. East Africans (Ethiopians), on the other hand, are more likely to exhibit duplications of the CYP2D6-gene (indicative of ultra-rapid metabolism), which predisposes them to serious adverse reactions ${ }^{16}$. Studying ethnic, racial, and genetic factors in opiate metabolism remains important in helping us individualize care for patients of all ages.

\section{Morphine}

Studies of morphine pharmacokinetics have been reported by several groups ${ }^{17,18}$. The focus here will be on the author's work (AL), which is known in detail. In 1987, a small study in 10 infants showed that they had pharmacokinetic parameters different from those reported in adults, and a lower $\mathrm{Cl}$ and large $\mathrm{Vd}$ resulted in a prolonged $\mathrm{t} 1 / 2^{19}$. Study of a larger cohort of 49 infants and toddlers, all receiving morphine by IV infusion after cardiac surgery, showed the same pattern; adult values for $\mathrm{Cl}$ were reached by the age of 6 months $^{20}$. A subsequent study of 26 infants who received morphine by IV infusion after non-cardiac surgeries found $\mathrm{Cl}$ in non-cardiac infants to be significantly greater than in infants after cardiac surgery, and non-cardiac surgical infants reached adult morphine $\mathrm{Cl}$ values by 1 to 3 months of age ${ }^{21}$. In all of these studies, inter-patient morphine $\mathrm{Cl}$ variability was high, giving values two- to three-fold different for same-aged infants, a problem seen with most "older" opiates ${ }^{17,22,23}$ (Figure 1). This variability makes it difficult to predict the duration of both desired and undesired morphine effects in any individual infant.

Klimas and Mikus recently suggested that active morphine metabolite morphine-6-glucuronide (M-6-G) was responsible for $85 \%$

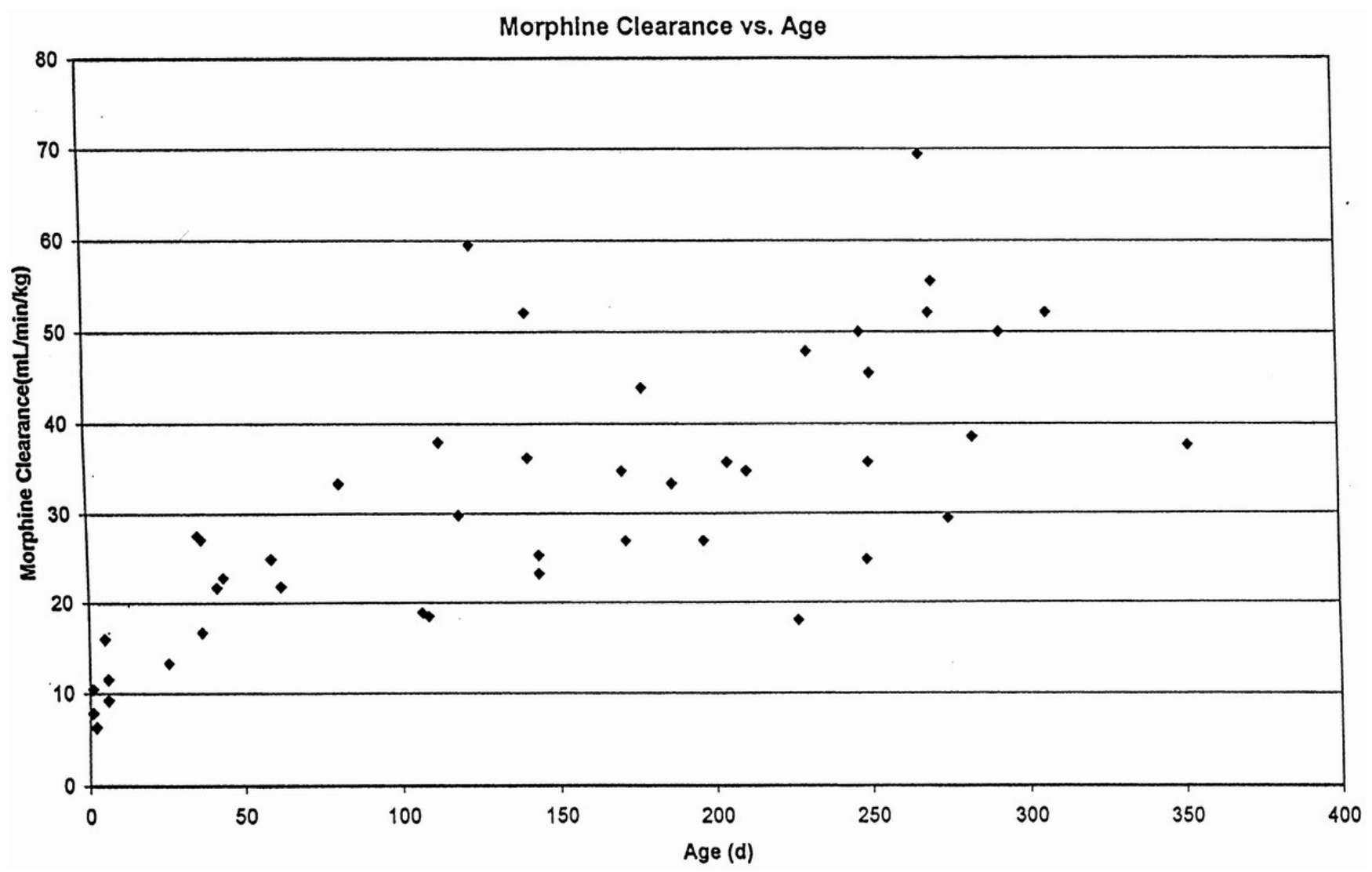

Figure 1. Morphine clearance $(\mathbf{m L} / \mathbf{m i n}$ per $\mathbf{k g})$ versus age in infants receiving morphine. Reprinted with permission from Wolters Kluwer Health $^{23}$. 
to $96 \%$ of morphine analgesia based upon a literature review of published studies reporting these concentrations in adults ${ }^{24}$. Bouwmeester et al. have reported M-6-G concentrations in infants in several reports but linking these concentrations or M-6-G/morphine ratios specifically to analgesia has not been analyzed ${ }^{17,25}$. Neonates and young infants have immature glucuronidation enzymes, and the amount of M-6-G that is produced in this population is unclear. The role of genetic polymorphisms in UDTtransferase glucuronidation also plays a role in inter-individual variability and is incompletely studied.

\section{Pharmacodynamics}

Pharmacodynamics refers to the effects of the drug on the patient; these may be therapeutic or undesired (adverse) ${ }^{2}$. For most clinicians, pharmacodynamics drives our administration of drugs. Pharmacodynamics are affected by many factors; for opiates, these include differences in receptor morphology (OPRM gene variant SNP $118 \mathrm{~A} / \mathrm{G})$, differences in target site concentrations of drug (ABCB 1/MDR 1 transporter), or effects downstream from drug reaching receptors and binding, such as differences in catecholO-methyltransferase (COMT) metabolism of catechols (472 G>A SNP). Studies of these genetic differences in opiate effects in different populations have been increasing and should continue to be an active area of research ${ }^{26-29}$. Genetic influences on pain perception also affect the pharmacodynamics of pain medications ${ }^{30,31}$.

Respiratory effects of opiates have been one of the factors limiting their use in infants. Studies linking drug concentrations to effects are few. In 1993, a study of morphine concentrations at steady state in 30 infants receiving IV morphine infusions after cardiac surgery found that a plasma morphine concentration of less than $20 \mathrm{ng} / \mathrm{mL}$ was associated with hypercarbia in $15 \%$ versus $67 \%$ in those with morphine concentrations over $20 \mathrm{ng} / \mathrm{mL}$, independent of age. This suggested that morphine infusions set to target a plasma concentration of $20 \mathrm{ng} / \mathrm{mL}$ could minimize the risk of respiratory depression in infant ${ }^{32}$. Unfortunately, the inter-patient variability in morphine pharmacokinetics makes predicting morphine concentration for an individual infant more difficult (see above discussion, Figure 1).

In 2000, a study of 83 infants demonstrated superior analgesia with morphine infusions compared with intermittent bolus dosing (high pain scores in $13 \%$ versus $32 \%)^{23}$. No difference in continuous oximetry readings of less than $90 \%$ in room air or time to oral intake was found. However, carbon dioxide $\left(\mathrm{CO}_{2}\right)$ response curve slopes did show evidence of ventilatory depression in $4(7 \%)$ out of 57 infusion-group infants.

A suggested course to facilitate extubation at surgery end is to use $0.05 \mathrm{mg} / \mathrm{kg}$ morphine as a loading dose, then infusion at 5 to 10 $\mu \mathrm{g} / \mathrm{kg}$ per hour in neonates, and 10 to $20 \mu \mathrm{g} / \mathrm{kg}$ per hour in infants, adjusting to each individual infant's response.

\section{Remifentanil}

The unpredictable pharmacokinetics and potential for undesired respiratory depression with morphine have led to the investigation of opioids with $\mathrm{Cl}$ that is less reliant on hepatic or renal function. Remifentanil is a mu-agonist, metabolized by tissue esterases, so its pharmacokinetics is unaffected by changes in hepatic or renal function. Important for use in infants, these tissue esterases are functional at birth, so age-related changes in pharmacokinetics have not been seen. Onset and offset are rapid, so IV infusion is the most common administration route. The context-sensitive half-time is reported as 3 to 5 minutes, independent of duration of infusion ${ }^{33}$. Davis et al. did a multi-center trial in 60 infants undergoing pyloromyotomy, comparing remifentanil infusion at $0.55 \pm 0.2 \mu \mathrm{g} / \mathrm{kg}$ per minute to halothane $0.4 \%$, with field block with bupivacaine for post-operative analgesia in both groups. Although there was no difference in time to extubation, no infant in the remifentanil group had any new abnormality on post-operative pneumograms, where three patients in the volatile-only group $\mathrm{did}^{34}$. Crawford et al. demonstrated that remifentanil can provide excellent conditions for orotracheal intubation in infants without the use of muscle relaxants. Twenty-four infants, pretreated with glycopyrrolate $10 \mu \mathrm{g} / \mathrm{kg}$, were randomly assigned to propofol/succinylcholine or propofol $/ \mathrm{remifentanil} 3 \mu \mathrm{g} / \mathrm{kg}$, and intubating conditions were similar with no adverse events ${ }^{35}$. A subsequent study including 64 children who were 0 to 3 years old, stratified in three age groups ( 0 to 3 months, 4 to 12 months, and 1 to 3 years) ${ }^{36}$, suggested that the age-specific bolus dose of remifentanil (ED50) to facilitate tracheal intubation is slightly higher $(3.7 \mu \mathrm{g} / \mathrm{kg})$ among the 4 to 12-month-old group. In this study, all patients were also pretreated with glycopyrrolate.

Undesired effects, including "chest wall rigidity" and bradycardia, have been reported, as can be seen with other fentanyl derivatives, and can lead to difficulty with ventilation and cardiovascular compromise. More importantly for anesthetic use, remifentanil analgesia is gone within 15 to 30 minutes of stopping infusions. Some authors have suggested that tachyphylaxis occurs quickly and that remifentanil use leads to higher opiate requirements; however, this has not been reported in infants.

Remifentanil avoids the challenges of pharmacokinetic variability that are seen with morphine; however, rapid offset can pose a challenge for post-operative analgesia. If post-operative pain can be approached with regional techniques, remifentanil seems a workable choice to allow early extubation after infant surgery.

\section{Regional anesthesia in infants}

Potential deleterious effects of anesthetic toxicity in the developing brain, as well as heightened awareness of negative long-term sequelae of exposure to painful stimuli early in life, have been recently highlighted $^{37-40}$. Regional anesthesia techniques, including local anesthetic infiltration, neuraxial blockade, and selective peripheral nerve blocks, have the potential benefit of decreasing anesthetic exposure during surgery as well as optimizing pain management in the post-operative period ${ }^{41,42}$. Decreasing opioid use while maintaining analgesia is particularly desirable in neonates and infants.

Regional techniques are technically challenging in newborns and infants and may require additional expertise. Assessment of risks versus benefits of regional anesthesia in infants is ongoing. Several large prospective multi-center studies, including the UK epidural audit $^{43}$ and the Pediatric Regional Anesthesia Network (PRAN) multi-center report ${ }^{44}$, demonstrate that regional anesthesia in children is safe, although neonates and infants are a small subset of the 
reported populations ${ }^{45}$. Despite the extremely low reported serious complication rates in all of these studies, case reports of permanent neurologic injury, including paralysis, exist in the literature ${ }^{46}$. Careful risk/benefit analysis, meticulous technique, and experience are recommended, especially prior to placing high lumbar or thoracic epidurals, where damage to the spinal cord can lead to devastating complications.

Over the past 15 years, improved equipment designed specifically for infants and neonates, increased utilization and quality of ultrasound technology, and emerging studies investigating the pharmacokinetics of local anesthetics in neonates have improved the safety and feasibility of regional anesthesia in this age group. Neonates and young infants are at a higher risk of local anesthetic toxicity because of immature enzyme systems and lower plasma protein levels ${ }^{45}$, which develop unpredictably with gestational age as well as vary from individual to individual ${ }^{47}$. Recent pharmacokinetic studies of epidural and peripheral local anesthetic in this age group contribute to the development of safe dosing guidelines. In 2012, Calder et al. studied 31 infants age 40 to 63 weeks postmenstrual age (post-menstrual age is the time between the first day of last menstrual period and birth [gestational age] plus the time elapsed after birth [chronological age]) having singleinjection or continuous epidural for hernia repairs and demonstrated safe plasma ropivacaine and bupivacaine levels without accumulation after doses of $1.5 \mathrm{mg} / \mathrm{kg}$ followed 2 hours later by $0.2 \mathrm{mg} / \mathrm{kg}$ per hour infusions ${ }^{48}$. Similarly, for single-injection peripheral nerve blocks, Suresh et al. demonstrated low plasma bupivacaine levels after single-shot transversus abdominis plane (TAP) blocks with $0.125 \%$ bupivacaine $1 \mathrm{~mL} / \mathrm{kg}$ in neonates ${ }^{49}$.

\section{Neuraxial}

Caudal block, which is most commonly employed for urologic, orthopedic, and general pediatric surgical procedures, provides post-operative pain relief; duration of the block depends on the local anesthetic type, volume, and adjuvants that are used ${ }^{50-52}$. Concern has been raised about neuraxial epinephrine and risk of spinal cord ischemia ${ }^{53}$. Epinephrine use should be reserved for initial test dosing with single-dose caudal or epidural neuraxial catheters and should be avoided as an additive in infusions. Opioids prolong the duration and may improve the quality of the block ${ }^{54}$, but the use as an adjuvant has been controversial because of associated side effects, including respiratory depression, nausea, pruritus, and urinary retention ${ }^{54,55}$. Whether the benefits of caudal epidural opioids outweigh the risks is actively debated ${ }^{56,57}$. Minimizing opioidrelated side effects post-operatively in infants and neonates may be best achieved by starting with opioid-free epidural infusions and supplementing with intermittent IV opioids if needed.

Clonidine has been shown to prolong the duration of epidural blocks ${ }^{58,59}$, although young infants seem particularly sensitive to sedating side effects and apnea may occur. For this reason, clonidine is not used as an adjuvant in infants of less than $10 \mathrm{~kg}$ at our institution. Safety data for neuraxial use of ketamine, midazolam, and neostigmine remain insufficient to support their use as epidural adjuvants $^{56}$.
Use of spinal block in pediatric patients remains limited and is used mainly as an awake technique for ex-premature infants at risk for post-operative apnea ${ }^{60}$. The duration of spinal anesthesia in children is less than 60 to 75 minutes and this requires close coordination between anesthesia and surgery as well as short surgical times ${ }^{61}$. However, spinal anesthesia provides a reliable, dense block and is useful for surgeries on the lower body in select patients.

\section{Peripheral nerve blocks}

Most well-described peripheral nerve blocks can be performed on neonates and infants. Precision is mandatory and meticulous attention must be given to the weight-based dosing limitation of local anesthetics. Axillary or femoral blocks can be used to facilitate peripherally inserted central catheter (PICC) line placement or treat limb ischemia ${ }^{62,63}$, illioinguinal or TAP blocks can be performed for trunk surgery ${ }^{49}$, and paravertebral blocks for thoracotomy ${ }^{64}$. Infants and neonates tend to have superficial, well-defined anatomy and tissue planes which can be visualized with high-frequency ultrasound. Excellent needle visualization is required to safely perform ultrasound-guided peripheral nerve blocks in this population.

\section{Interesting new trends in opiate development}

Another area of active research is the development of "biased ligands" of the mu-opioid receptor (MOR). Biased ligands are molecules that can discriminatively engage signaling pathways of a receptor ${ }^{65}$, offering the advantage of separating desirable (analgesic) from undesirable (respiratory depression, constipation, nausea) opiate effects. Research suggests that, for the MOR, opioid-induced analgesia is due to signaling of $\mathrm{G}$ protein-coupling inhibition of nociception but that side effects are modulated by signaling of beta-arrestin ${ }^{66,67}$. Novel biased ligands have been developed based on the concept of selective signaling. TRV130, a novel MOR G protein-biased ligand, has shown potent analgesic effect with minimal gastrointestinal dysfunction and respiratory suppression compared with morphine in rodents ${ }^{68}$. In humans, a phase III clinical trial in adult male volunteers reported that low doses of TRV130 ( 1.5 and $3 \mathrm{mg}$ ) were well tolerated, demonstrating a better analgesic response with less reduction of respiratory drive and nausea when compared with $10 \mathrm{mg}$ of morphine ${ }^{69}$. Higher doses of TRV130 (4 mg) also produced less respiratory depression than morphine but were associated with increased reports of nausea and headache. Another molecule recently identified, PZM21, also shows selective activation of the G-protein pathway with a better side effect profile compared with TRV130 in rodents ${ }^{70}$. However, human studies are not yet available. Development of opioid-biased ligands is an exciting area of new drug development that has not reached the point of pediatric investigation but that suggests a theoretical alternative for opioid analgesic treatment for infants with a better analgesic-to-adverse effect ratio.

Much recent attention in adults and adolescents has concerned the problem of long-term use of opiates and best practices to minimize this risk ${ }^{71}$. We believe this is an important issue but needs to be balanced by concerns of long-term effects of undertreating pain in infants. 


\section{Non-opiate analgesics}

Depending on the patient and procedure, other categories of analgesics may be considered to complement or replace opioids. Table 1 summarizes the analgesics described in this article. Description of the pharmacokinetics/dynamics in infants of acetaminophen (focusing on IV route) and of ketorolac (the only widely available parenteral non-steroidal anti-inflammatory drug [NSAID] in the US) may be of particular benefit in infants as they do not work via opiate receptors and do not have effects on respiration or consciousness.

\section{Ketorolac}

Ketorolac tromethamine is available in oral and parenteral forms. As the only widely available IV NSAID in the US, it has been used as an analgesic adjunct and has been shown to decrease opioid requirements in post-operative patients. It works by inhibiting the cyclooxygenase system which decreases prostaglandin synthesis and the inflammatory cascade. It does not affect consciousness or respiration but does have effects on gastric mucosa, renal perfusion, and platelet function. Baseline renal or platelet dysfunction is a relative contraindication.

A prospective randomized trial of 70 infants and children showed no difference in chest tube drainage or bleeding complications and no difference in median change in creatinine after congenital cardiac surgery with or without 48 hours of ketorolac therapy post-operatively ${ }^{72}$. Aldrink et al. reported a retrospective review of 57 infants who received multiple doses of ketorolac (mean of eight doses every 6 hours) post-operatively. Ten had a bleeding event (three required transfusion). Risk factors identified were age of less than 21 days and gestational age of less than 37 weeks $^{73}$.

To further explore the pharmacokinetic, safety, and respiratory effects in infants, we did a single-center randomized, blinded, placebo-controlled study in infants 6 to 18 months admitted after surgery. The kinetics analyses were done for stereo-specific isomers since animal studies suggested that the S-isomer was a more potent analgesic ${ }^{74}$ and studies in children suggested differences in isomer handling ${ }^{75,76}$. Thirty-seven infants were enrolled, 23 following craniectomy surgery. All received morphine for breakthrough pain. A marked difference in isomer $\mathrm{Cl}$ was found, with the $\mathrm{S}$-isomer cleared fourfold faster than the R-isomer $(4.4 \pm 2.8 \mathrm{~mL} / \mathrm{min}$ per $\mathrm{kg}$ versus $1.0 \pm 0.6$, respectively). The $\mathrm{t} 1 / 2$ was $64 \pm 24$ minutes (S) versus $198 \pm 77$ minutes $(R)$. Serum concentrations of the $S$-isomer fell below adult "therapeutic" values (as reported by Stanski et al.) by 4 hours. Modeling of doses of $0.5 \mathrm{mg} / \mathrm{kg}$ or $1 \mathrm{mg} / \mathrm{kg}$ showed complete $\mathrm{Cl}$ of the $\mathrm{S}$-isomer by 4 hours, but accumulation of the Risomer with each dose. As a single-dose study, no adverse effects on renal function (creatinine and urine volume), gastric mucosa (guaiac testing), or platelet function (surgical drain amount in craniectomy babies) were observed. Continuous oximetry showed no episodes of desaturation in either placebo or ketorolac groups. Unanswered is the possibility that toxicity may relate to the R-isomer concentrations which rise with repeat dosing ${ }^{77}$. In 2- to 6-month-old infants, when the same protocol was used, similar results were found, and the $\mathrm{S}$-isomer cleared fivefold faster than the R-isomer of ketorolac. The $t \frac{1}{2}$ was 33 minutes $(S)$ versus 191 minutes $(R)^{78}$. Safety data are limited in neonates or infants at higher risk for renal dysfunction except in the studies by Gupta et al. and Aldrink et al. detailed above, and caution is advised in this patient population. In our institution, we administer ketorolac $0.5 \mathrm{mg} / \mathrm{kg}$ every 6 to 8 hours for a maximum of 72 hours to infants older than 6 months and a single dose $0.5 \mathrm{mg} / \mathrm{kg}$ for infants 1 to 6 months. Although the retrospective review by Aldrink et al. in a 0- to 3-month-old age group suggests that scheduled dosing of ketorolac may be well tolerated in those over 3 weeks of age or over 37 weeks' gestational age, pharmacokinetic and prospective safety data for this practice are based on small samples.

\section{Acetaminophen}

Acetaminophen (or paracetamol in European or UK literature) is the most widely used analgesic/antipyretic administered in oral or rectal forms. In 2002, propacetamol, an IV pro-drug, was developed, and in 2009 an IV active form of acetaminophen became

Table 1. Pharmacokinetic and clinical considerations of common analgesic medications in infants.

\begin{tabular}{|c|c|c|c|c|c|}
\hline Medication & Metabolism & Metabolite & $\begin{array}{l}\text { Renal } \\
\text { excretion }\end{array}$ & $\begin{array}{l}\text { Pharmacokinetic } \\
\text { considerations }\end{array}$ & $\begin{array}{l}\text { Clinical } \\
\text { considerations }\end{array}$ \\
\hline Morphine & Hepatic & Yes, active & Yes & $\begin{array}{l}\text { Inter-individual } \\
\text { variability }\end{array}$ & $\begin{array}{l}\text { Titrate to effect, } \\
\text { small doses of } \\
0.05 \mathrm{mg} / \mathrm{kg}\end{array}$ \\
\hline Remifentanil & $\begin{array}{l}\text { Plasma } \\
\text { esterase }\end{array}$ & No & No & $\begin{array}{l}\text { Predictable } \\
\text { duration }\end{array}$ & $\begin{array}{l}\text { No long-acting } \\
\text { analgesia }\end{array}$ \\
\hline Ketorolac & Hepatic & $\begin{array}{l}\text { Yes, isomers } \\
\text { different }\end{array}$ & Yes & $\begin{array}{l}\text { R-isomer } \\
\text { accumulation }\end{array}$ & $\begin{array}{l}\text { Single dose } \\
\text { only for infants } \\
<6 \text { months old. } \\
\text { For patients > } 6 \\
\text { months old, limit } \\
\text { Q6 hour dosing } \\
\text { to } 72 \text { hours total } \\
\text { duration. }\end{array}$ \\
\hline Acetaminophen & Hepatic & Yes, toxic & No & $\begin{array}{l}\text { Intravenous } \\
\text { formulation }\end{array}$ & $\begin{array}{l}\text { Every-6-hour } \\
\text { dosing interval } \\
\text { preferred }\end{array}$ \\
\hline
\end{tabular}


available in Europe. In the US, IV acetaminophen was approved by the US Food and Drug Administration more recently, so many of the reports on its use come from European or UK sites. One advantage of this drug is its long history of use in the oral form, meaning that safety information in children and infants is available. Hepatic toxicity from overdose of acetaminophen and accumulation of the metabolite N-acetyl-p-benzoquinone imine (NAPQI) is very uncommon in infants because they have immature function of P450 enzyme, specifically CYP2E1, and make much lower concentrations of this metabolite. The ideal analgesic concentration has been incompletely studied, but Anderson et al. reported that acetaminophen concentrations of $10 \mathrm{mg} / \mathrm{L}$ resulted in analgesia in children post-tonsillectomy ${ }^{79}$. This concentration is commonly targeted as therapeutic but whether it applies in all circumstances is unexplored.

In 2005, Anderson et al. reported a population pharmacokinetic study of IV propacetamol in children. The authors included 846 acetaminophen concentrations from seven previous studies in a total of 144 children. The bioavailability was $0.5, \mathrm{Cl}$ was $16 \mathrm{~L} /$ hour per $70 \mathrm{~kg}$, increasing from $1.27 \mathrm{~L} /$ hour per $70 \mathrm{~kg}$ in premature infants (gestation 27 weeks) to $84 \%$ of adult values by age 1 year. $\mathrm{Vd}$ (peripheral) decreased from $45 \mathrm{~L} / 70 \mathrm{~kg}$ in prematures (27 weeks) to adult values by the age of 6 months. The authors predicted that dosing of propacetamol of $30 \mathrm{mg} / \mathrm{kg}(15 \mathrm{mg} / \mathrm{kg}$ paracetamol) every 6 hours would result in acetaminophen concentrations of $10 \mathrm{mg} / \mathrm{L}$ in pediatric patients ${ }^{80}$.

Allegaert et al. (2004) reported kinetics of a single dose of IV acetaminophen in 30 neonates showing lower $\mathrm{Cl}$ in infants of less than 37 weeks' gestation $(8.1 \mathrm{~L} /$ hour per $70 \mathrm{~kg}$ ) compared with those of 37 to 41 weeks' gestation (11.9 L/hour per $70 \mathrm{~kg}$ ), noting marked inter-patient variability. The $\mathrm{t} 1 / 2$ was prolonged at 277 minutes in the premature group compared with 172 minutes in the term infants, and again large variability was noted ${ }^{81}$. Population pharmacokinetics of acetaminophen in infants was reported by Allegaert et al. in 2011. They included 158 neonates ( 58 prematurely born) from four studies with 943 acetaminophen concentration. $\mathrm{Cl}$ from this larger group of infants was $5 \mathrm{~L} /$ hour per $70 \mathrm{~kg}$, and adult $\mathrm{Cl}$ of $16.2 \mathrm{~L} /$ hour per $70 \mathrm{~kg}$ was found at the age of 1 year. The authors' suggestion was use of one loading dose of $20 \mathrm{mg} / \mathrm{kg}$ followed by $10 \mathrm{mg} / \mathrm{kg}$ every 6 hours to target an acetaminophen concentration of $11 \mathrm{mg} / \mathrm{L}$ in infants with a gestational age of 32 to 44 weeks $^{82}$.

The safety profile and kinetics of IV acetaminophen were studied by Palmer et al. in 50 neonates given repeated doses postoperatively $^{83}$. Cl was $5.2 \mathrm{~L} /$ hour per $70 \mathrm{~kg}$, with a large $\mathrm{Vd}$ of 76 $\mathrm{L} / 70 \mathrm{~kg}$. Elevated bilirubin was correlated with decreased Cl. Daily hepatic enzyme levels remained normal in 49 of the 50 infants, increasing in one after five doses and recovering when acetaminophen was stopped. The authors suggest $15 \mathrm{mg} / \mathrm{kg}$ dosing every 6 hours in term infants and a reduction for hyperbilirubinemia ${ }^{83}$.
Ceelie et al. did a blinded randomized controlled trial in 71 infants, born after 37 weeks gestation up to 1 year of age, treated after major abdominal or thoracic surgery. Infants received IV acetaminophen $30 \mathrm{mg} / \mathrm{kg}$ per day in four doses or morphine IV infusions at 4 to $16 \mu \mathrm{g} / \mathrm{kg}$ per hour after a standardized anesthetic with one dose of morphine 30 minutes before surgery end. Rescue for pain was with morphine bolus dosing in both groups. Pain scores and the number needing rescue were the same in both groups. Total morphine was lower in the acetaminophen group $(122 \mu \mathrm{g} / \mathrm{kg}$ over 48 hours versus $357 \mu \mathrm{g} / \mathrm{kg}$ per 48 hours); naloxone was given to three in the morphine group and none in the acetaminophen group $(P=\text { not significant })^{84}$.

\section{Conclusions}

The clinical application of pharmacokinetic/pharmacodynamics of opiates (morphine or remifentanil) or NSAIDs (ketorolac or IV acetaminophen) to our care of infants who require surgery has room for much further study. Further investigation of biased ligand compounds which may be able to separate analgesia (G-protein activation) from side effects (beta-arrestin recruitment) may offer distinct advantages in infant peri-operative care. Until then, it seems reasonable to consider multi-modal therapy to minimize undesirable opiate side effects. Variability of $\mathrm{Cl}$ of older opiates such as morphine supports using small doses $(0.05 \mathrm{mg} / \mathrm{kg}$ morphine $)$ and titrating for effect. Remifentanil avoids the variability issue but requires infusion to maintain effect, and analgesia is gone quickly $(<30$ minutes) once it is discontinued, which may not be appropriate for the post-operative infant. Regional analgesic techniques can help bridge intra-operative to post-operative analgesia but require practitioners skilled in its use in these smallest patients.

Ketorolac in a single-dose study did not show adverse effects on hepatic, gastrointestinal, or renal function but raises the concern of accumulation of the R-isomer with repeated doses and its unknown relation to toxicity. Small retrospective studies suggest caution in ketorolac use in prematures (born at $<37$ weeks) or in young neonates ( $<3$ weeks). For infants, acetaminophen does have IV kinetic information available to guide dosing and therefore can be a part of a multi-modal analgesic regime in most infants. Nonpharmacologic adjuncts which we have not presented in this forum, including use of oral glucose, non-nutritive sucking, and swaddling, should also be considered.

\section{Competing interests}

The authors declare that they have no competing interests.

\section{Grant information}

The author(s) declared that no grants were involved in supporting this work. 
1. Behrman RE, Kliegman R, Jenson HB, editor: Nelson Textbook of Pediatrics. 17 ed: Elselvier; 2004.

Reference Source

2. Davis $P$, Cladis F, Motoyama E, editor: Smith's Anesthesia for Infants and Children. 8 ed: Elsevier; 2011.

Reference Source

3. Hughes MA, Glass PS, Jacobs JR: Context-sensitive half-time in multicompartment pharmacokinetic models for intravenous anesthetic drugs. Anesthesiology. 1992; 76(3): 334-41.

PubMed Abstract | Publisher Full Text

4. Anderson BJ: Pediatric models for adult target-controlled infusion pumps. Paediatr Anaesth. 2010; 20(3): 223-32. PubMed Abstract | Publisher Full Text

5. Anderson BJ, Hodkinson B: Are there still limitations for the use of targetcontrolled infusion in children? Curr Opin Anaesthesiol. 2010; 23(3): 356-62. PubMed Abstract | Publisher Full Text

6. Krekels EH, DeJongh J, van Lingen RA, et al:: Predictive performance of a recently developed population pharmacokinetic model for morphine and its metabolites in new datasets of (preterm) neonates, infants and children. Clin Pharmacokinet. 2011; 50(1): 51-63.

PubMed Abstract | Publisher Full Text

7. Krekels EH, Tibboel D, Danhof M, et al.: Prediction of morphine clearance in the paediatric population: how accurate are the available pharmacokinetic models? Clin Pharmacokinet. 2012; 51(11): 695-709.

PubMed Abstract | Publisher Full Text

8. F Wang C, Allegaert K, Peeters MY, et al.: The allometric exponent for scaling clearance varies with age: a study on seven propofol datasets ranging from preterm neonates to adults. Br J Clin Pharmacol. 2014; 77(1): 149-59. PubMed Abstract | Publisher Full Text | Free Full Text | F1000 Recommendation

9. Jimenez N, Galinkin JL: Personalizing pediatric pain medicine: using population-specific pharmacogenetics, genomics, and other -omics approaches to predict response. Anesth Analg. 2015; 121(1): 183-7. PubMed Abstract | Publisher Full Text

10. Ciszkowski C, Madadi P, Phillips MS, et al:: Codeine, ultrarapid-metabolism genotype, and postoperative death. N Engl J Med. 2009; 361(8): 827-8. PubMed Abstract | Publisher Full Text

11. F Kelly LE, Rieder M, van den Anker J, et al:: More codeine fatalities after tonsillectomy in North American children. Pediatrics. 2012; 129(5): e1343-7. PubMed Abstract | Publisher Full Text | F1000 Recommendation

12. Williams DG, Patel A, Howard RF: Pharmacogenetics of codeine metabolism in an urban population of children and its implications for analgesic reliability. $\mathrm{Br}$ $J$ Anaesth. 2002; 89(6): 839-45.

PubMed Abstract | Publisher Full Text

13. Crews KR, Gaedigk A, Dunnenberger HM, et al.: Clinical Pharmacogenetics Implementation Consortium guidelines for cytochrome P450 2D6 genotype and codeine therapy: 2014 update. Clin Pharmacol Ther. 2014; 95(4): 376-82. PubMed Abstract | Publisher Full Text | Free Full Text

14. Crews KR, Gaedigk A, Dunnenberger HM, et al.: Clinical Pharmacogenetics Implementation Consortium (CPIC) guidelines for codeine therapy in the context of cytochrome P450 2D6 (CYP2D6) genotype. Clin Pharmacol Ther 2012; 91(2): 321-6.

PubMed Abstract | Publisher Full Text | Free Full Text

15. Bradford LD: CYP2D6 allele frequency in European Caucasians, Asians, Africans and their descendants. Pharmacogenomics. 2002; 3(2): 229-43. PubMed Abstract | Publisher Full Text

16. Aklillu E, Persson I, Bertilsson L, et al.: Frequent distribution of ultrarapid metabolizers of debrisoquine in an ethiopian population carrying duplicated and multiduplicated functional CYP2D6 alleles. J Pharmacol Exp Ther. 1996; 278(1): 441-6.

PubMed Abstract

17. Bouwmeester NJ, Anderson BJ, Tibboel D, et al:: Developmental pharmacokinetics of morphine and its metabolites in neonates, infants and young children. $\mathrm{Br} J$ Anaesth. 2004; 92(2): 208-17.

PubMed Abstract | Publisher Full Text

18. Saarenmaa E, Neuvonen PJ, Rosenberg P, et al.: Morphine clearance and effects in newborn infants in relation to gestational age. Clin Pharmacol Ther. 2000; 68(2): 160-6.

PubMed Abstract | Publisher Full Text

19. Lynn AM, Slattery JT: Morphine pharmacokinetics in early infancy. Anesthesiology. 1987; 66(2): 136-9.

PubMed Abstract

20. McRorie TI, Lynn AM, Nespeca MK, et al:: The maturation of morphine clearance and metabolism. Am J Dis Child. 1992; 146(8): 972-6.

PubMed Abstract | Publisher Full Text

21. Lynn A, Nespeca MK, Bratton SL, et al:: Clearance of morphine in postoperative infants during intravenous infusion: the influence of age and surgery. Anesth Analg. 1998; 86(5): 958-63.

PubMed Abstract | Publisher Full Text
22. F Krekels EH, Tibboel D, de Wildt SN, et al:: Evidence-based morphine dosing for postoperative neonates and infants. Clin Pharmacokinet. 2014; 53(6): 553-63.

PubMed Abstract | Publisher Full Text | F1000 Recommendation

23. Lynn AM, Nespeca MK, Bratton SL, et al.: Intravenous morphine in postoperative infants: intermittent bolus dosing versus targeted continuous infusions. Pain. 2000; 88(1): 89-95.

PubMed Abstract | Publisher Full Text

24. F Klimas R, Mikus G: Morphine-6-glucuronide is responsible for the analgesic effect after morphine administration: a quantitative review of morphine, morphine-6-glucuronide, and morphine-3-glucuronide. Br J Anaesth. 2014; 113(6): 935-44.

PubMed Abstract | Publisher Full Text | F1000 Recommendation

25. Bouwmeester NJ, van den Anker JN, Hop WC, et al:: Age- and therapy-related effects on morphine requirements and plasma concentrations of morphine and its metabolites in postoperative infants. Br J Anaesth. 2003; 90(5): 642-52. PubMed Abstract | Publisher Full Text

26. F Oertel BG, Schmidt R, Schneider A, et al.: The mu-opioid receptor gene polymorphism $118 \mathrm{~A}>\mathrm{G}$ depletes alfentanil-induced analgesia and protects against respiratory depression in homozygous carriers. Pharmacogenet Genomics. 2006; 16(9): 625-36.

PubMed Abstract | Publisher Full Text | F1000 Recommendation

27. F Campa D, Gioia A, Tomei A, et al.: Association of ABCB1/MDR1 and OPRM1 gene polymorphisms with morphine pain relief. Clin Pharmacol Ther. 2008; 83(4): 559-66.

PubMed Abstract | Publisher Full Text | F1000 Recommendation

28. Rakvåg TT, Klepstad P, Baar C, et al.: The Val158Met polymorphism of the human catechol-O-methyltransferase (COMT) gene may influence morphine requirements in cancer pain patients. Pain. 2005; 116(1-2): 73-8. PubMed Abstract | Publisher Full Text

29. Berthele A, Platzer S, Jochim B, et al:: COMT Val ${ }^{108 / 158}$ Met genotype affects the mu-opioid receptor system in the human brain: evidence from ligand-binding, G-protein activation and preproenkephalin mRNA expression. Neuroimage. 2005; 28(1): 185-93.

PublMed Abstract | Publisher Full Text

30. F Angst MS, Phillips NG, Drover DR, et al:: Pain sensitivity and opioid analgesia: a pharmacogenomic twin study. Pain. 2012; 153(7): 1397-409. PubMed Abstract | Publisher Full Text | Free Full Text | F1000 Recommendation

31. Smith MT, Muralidharan A: Pharmacogenetics of pain and analgesia. Clin Genet. 2012; 82(4): 321-30.

PubMed Abstract | Publisher Full Text

32. Lynn AM, Nespeca MK, Opheim KE, et al:: Respiratory effects of intravenous morphine infusions in neonates, infants, and children after cardiac surgery. Anesth Analg. 1993; 77(4): 695-701.

PubMed Abstract | Publisher Full Text

33. Ross AK, Davis PJ, Dear Gd GL, et al:: Pharmacokinetics of remifentanil in anesthetized pediatric patients undergoing elective surgery or diagnostic procedures. Anesth Analg. 2001; 93(6): 1393-401, table of contents.

PubMed Abstract | Publisher Full Text

34. Davis PJ, Galinkin J, McGowan FX, et al:: A randomized multicenter study of remifentanil compared with halothane in neonates and infants undergoing pyloromyotomy. I. Emergence and recovery profiles. Anesth Analg. 2001; 93(6) 1380-6, table of contents.

PubMed Abstract | Publisher Full Text

35. Crawford MW, Hayes J, Tan JM: Dose-response of remifentanil for tracheal intubation in infants. Anesth Analg. 2005; 100(6): 1599-604. PubMed Abstract | Publisher Full Text

36. F Hume-Smith H, McCormack J, Montgomery C, et al:: The effect of age on the dose of remifentanil for tracheal intubation in infants and children. Paediatr Anaesth. 2010; 20(1): 19-27.

PubMed Abstract | Publisher Full Text | F1000 Recommendation

37. Sun L: Early childhood general anaesthesia exposure and neurocognitive development. Br J Anaesth. 2010; 105 Suppl 1: i61-8. PubMed Abstract | Publisher Full Text | Free Full Text

38. F Vutskits L, Xie Z: Lasting impact of general anaesthesia on the brain: mechanisms and relevance. Nat Rev Neurosci. 2016; 17(11): 705-17. PubMed Abstract | Publisher Full Text | F1000 Recommendation

39. Vutskits L: More Than Anyone Else: Preemies Need Good Analgesia. Anesthesiology. 2016; 124(4): 758-60.

PubMed Abstract | Publisher Full Text

40. Lin EP, Soriano SG, Loepke AW: Anesthetic neurotoxicity. Anesthesiol Clin. 2014 32(1): 133-55

PubMed Abstract | Publisher Full Text

41. F Walker SM, Fitzgerald M, Hathway GJ: Surgical injury in the neonatal rat alters the adult pattern of descending modulation from the rostroventral medulla. Anesthesiology. 2015; 122(6): 1391-400.

PubMed Abstract | Publisher Full Text | Free Full Text | F1000 Recommendation 
42. Bosenberg A: Benefits of regional anesthesia in children. Paediatr Anaesth 2012; 22(1): 10-8.

PubMed Abstract | Publisher Full Text

43. F Llewellyn N, Moriarty A: The national pediatric epidural audit. Paediatr Anaesth. 2007; 17(6): 520-33.

PubMed Abstract | Publisher Full Text | F1000 Recommendation

44. F Polaner DM, Taenzer AH, Walker BJ, et al:: Pediatric Regional Anesthesia Network (PRAN): a multi-institutional study of the use and incidence of complications of pediatric regional anesthesia. Anesth Analg. 2012; 115(6): 1353-64.

PubMed Abstract | Publisher Full Text | F1000 Recommendation

45. F Long JB, Joselyn AS, Bhalla T, et al:: The Use of Neuraxial Catheters for Postoperative Analgesia in Neonates: A Multicenter Safety Analysis from the Pediatric Regional Anesthesia Network. Anesth Analg. 2016; 122(6): 1965-70. PubMed Abstract | Publisher Full Text | F1000 Recommendation

46. Meyer MJ, Krane EJ, Goldschneider KR, et al:: Case report: neurological complications associated with epidural analgesia in children: a report of 4 cases of ambiguous etiologies. Anesth Analg. 2012; 115(6): 1365-70. PubMed Abstract | Publisher Full Text

47. Bosenberg AT, Thomas J, Cronje L, et al.: Pharmacokinetics and efficacy of ropivacaine for continuous epidural infusion in neonates and infants. Paediat Anaesth. 2005; 15(9): 739-49.

PubMed Abstract | Publisher Full Text

48. F Calder A, Bell GT, Andersson M, et al:: Pharmacokinetic profiles of epidural bupivacaine and ropivacaine following single-shot and continuous epidural use in young infants. Paediatr Anaesth. 2012; 22(5): 430-7. PubMed Abstract | Publisher Full Text | F1000 Recommendation

49. F Suresh S, De Oliveira GS Jr: Blood Bupivacaine Concentrations After Transversus Abdominis Plane Block in Neonates: A Prospective Observational Study. Anesth Analg. 2016; 122(3): 814-7.

PubMed Abstract | Publisher Full Text | F1000 Recommendation

50. Ansermino M, Basu R, Vandebeek C, et al:: Nonopioid additives to local anaesthetics for caudal blockade in children: a systematic review. Paediatr Anaesth. 2003; 13(7): 561-73.

PubMed Abstract | Publisher Full Text

51. Gunter JB, Dunn CM, Bennie JB, et al: Optimum concentration of bupivacaine for combined caudal--general anesthesia in children. Anesthesiology. 1991; 75(1): 57-61. PubMed Abstract

52. Hong J, Han SW, Kim WO, et al: A comparison of high volume/low concentration and low volume/high concentration ropivacaine in cauda analgesia for pediatric orchiopexy. Anesth Analg. 2009; 109(4): 1073-8. PubMed Abstract | Publisher Full Text

53. Berde C, Greco C: Pediatric regional anesthesia: drawing inferences on safety from prospective registries and case reports. Anesth Analg. 2012; 115(6): 1259-62.

PubMed Abstract | Publisher Full Text

54. Krane EJ, Tyler DC, Jacobson LE: The dose response of caudal morphine in children. Anesthesiology. 1989; 71(1): 48-52.

PubMed Abstract | Publisher Full Text

55. Krane EJ: Delayed respiratory depression in a child after caudal epidural morphine. Anesth Analg. 1988; 67(1): 79-82.

PubMed Abstract | Publisher Full Text

56. Jöhr M, Berger TM: Caudal blocks. Paediatr Anaesth. 2012; 22(1): 44-50. PubMed Abstract | Publisher Full Text

57. Lönnqvist PA, Ivani G, Moriarty $\mathrm{T}$ : Use of caudal-epidural opioids in children still state of the art or the beginning of the end? Paediatr Anaesth. 2002; 12(9): 747-9.

PubMed Abstract | Publisher Full Text

58. Singh R, Kumar N, Singh P: Randomized controlled trial comparing morphine or clonidine with bupivacaine for caudal analgesia in children undergoing upper abdominal surgery. Br J Anaesth. 2011; 106(1): 96-100. PubMed Abstract | Publisher Full Text

59. F Vetter TR, Carvallo D, Johnson JL, et al:: A comparison of single-dose caudal clonidine, morphine, or hydromorphone combined with ropivacaine in pediatric patients undergoing ureteral reimplantation. Anesth Analg. 2007 104(6): 1356-63, table of contents.

PubMed Abstract | Publisher Full Text | F1000 Recommendation

60. Puncuh $\mathrm{F}$, Lampugnani $\mathrm{E}$, Kokki $\mathrm{H}$ : Spinal anaesthesia in paediatric patients. Curr Opin Anaesthesiol. 2005; 18(3): 299-305. PubMed Abstract | Publisher Full Text

61. Kokki H: Spinal blocks. Paediatr Anaesth. 2012; 22(1): 56-64. PubMed Abstract | Publisher Full Text

62. Messeri A, Calamandrei M: Percutaneous central venous catheterization in small infants: axillary block can facilitate the insertion rate. Paediatr Anaesth. 2000; 10(5): 527-30.

PubMed Abstract | Publisher Full Text

63. Breschan C, Kraschl R, Jost R, et al:: Axillary brachial plexus block for treatment of severe forearm ischemia after arterial cannulation in an extremely low birthweight infant. Paediatr Anaesth. 2004; 14(8): 681-4.

PubMed Abstract | Publisher Full Text
64. F Boretsky K, Visoiu M, Bigeleisen P: Ultrasound-guided approach to the paravertebral space for catheter insertion in infants and children. Paediatr Anaesth. 2013; 23(12): 1193-8.

PubMed Abstract | Publisher Full Text | F1000 Recommendation

65. Kenakin T: Functional selectivity and biased receptor signaling. $J$ Pharmacol Exp Ther. 2011; 336(2): 296-302. PubMed Abstract | Publisher Full Text

66. Bohn LM, Gainetdinov RR, Lin FT, et al.: Mu-opioid receptor desensitization by beta-arrestin-2 determines morphine tolerance but not dependence. Nature. 2000; 408(6813): 720-3.

PubMed Abstract | Publisher Full Text

67. Peethambaram PP, Melisko ME, Rinn KJ, et al:: A phase I trial of immunotherapy with lapuleucel-T (APC8024) in patients with refractory metastatic tumors that express HER-2/neu. Clin Cancer Res. 2009; 15(18): 5937-44.

PubMed Abstract | Publisher Full Text | Free Full Text

68. F DeWire SM, Yamashita DS, Rominger DH, et al:: A G protein-biased ligand at the $\mu$-opioid receptor is potently analgesic with reduced gastrointestinal and respiratory dysfunction compared with morphine. J Pharmacol Exp Ther. 2013; 344(3): $708-17$.

PubMed Abstract | Publisher Full Text | F1000 Recommendation

69. F Soergel DG, Subach RA, Burnham N, et al.: Biased agonism of the $\mu$-opioid receptor by TRV 130 increases analgesia and reduces on-target adverse effects versus morphine: A randomized, double-blind, placebo-controlled, crossover study in healthy volunteers. Pain. 2014; 155(9): 1829-35.

PubMed Abstract | Publisher Full Text | F1000 Recommendation

70. F Manglik A, Lin H, Aryal DK, et al.: Structure-based discovery of opioid analgesics with reduced side effects. Nature. 2016; 537(7619): 185-90. PubMed Abstract | Publisher Full Text | Free Full Text | F1000 Recommendation

71. F Dart RC, Severtson SG, Bucher-Bartelson B: Trends in opioid analgesic abuse and mortality in the United States. N Engl J Med. 2015; 372(16): 1573-4. PubMed Abstract | Publisher Full Text | F1000 Recommendation

72. Gupta A, Daggett C, Drant S, et al.: Prospective randomized trial of ketorolac after congenital heart surgery. $J$ Cardiothorac Vasc Anesth. 2004; 18(4): 454-7. PubMed Abstract | Publisher Full Text

73. Aldrink $\mathrm{JH}$, Ma M, Wang $\mathrm{W}$, et al.: Safety of ketorolac in surgical neonates and infants 0 to 3 months old. J Pediatr Surg. 2011; 46(6): 1081-5. PubMed Abstract | Publisher Full Text

74. Jett MF, Ramesha CS, Brown CD, et al: Characterization of the analgesic and anti-inflammatory activities of ketorolac and its enantiomers in the rat. $J$ Pharmacol Exp Ther. 1999; 288(3): 1288-97. PubMed Abstract

75. Hamunen K, Maunuksela EL, Sarvela J, et al.: Stereoselective pharmacokinetics of ketorolac in children, adolescents and adults. Acta Anaesthesiol Scand. 1999; 43(10): 1041-6.

PubMed Abstract | Publisher Full Text

76. Kauffman RE, Lieh-Lai MW, Uy HG, et al.: Enantiomer-selective pharmacokinetics and metabolism of ketorolac in children. Clin Pharmacol Ther. 1999; 65(4): 382-8.

PubMed Abstract | Publisher Full Text

77. Lynn AM, Bradford H, Kantor ED, et al:: Ketorolac tromethamine: stereo-specific pharmacokinetics and single-dose use in postoperative infants aged 2-6 months. Paediatr Anaesth. 2011; 21(3): 325-34.

PubMed Abstract | Publisher Full Text | Free Full Text

78. Lynn AM, Bradford H, Kantor ED, et al.: Postoperative ketorolac tromethamine use in infants aged 6-18 months: the effect on morphine usage, safety assessment, and stereo-specific pharmacokinetics. Anesth Analg. 2007; 104(5): $1040-51$, tables of contents.

PubMed Abstract | Publisher Full Text

79. Anderson BJ, Woollard GA, Holford $\mathrm{NH}$ : Acetaminophen analgesia in children: placebo effect and pain resolution after tonsillectomy. Eur J Clin Pharmacol. 2001; 57(8): 559-69.

PubMed Abstract | Publisher Full Text

80. Anderson BJ, Pons G, Autret-Leca E, et al.: Pediatric intravenous paracetamol (propacetamol) pharmacokinetics: a population analysis. Paediatr Anaesth 2005; 15(4): 282-92.

PubMed Abstract | Publisher Full Text

81. Allegaert K, Van der Marel CD, Debeer A, et al:: Pharmacokinetics of single dose intravenous propacetamol in neonates: effect of gestational age. Arch Dis Child Fetal Neonatal Ed. 2004; 89(1): F25-8. PubMed Abstract | Publisher Full Text | Free Full Text

82. Allegaert K, Palmer GM, Anderson BJ: The pharmacokinetics of intravenous paracetamol in neonates: size matters most. Arch Dis Child. 2011; 96(6): 575-80. PubMed Abstract | Publisher Full Text

83. Palmer GM, Atkins M, Anderson BJ, et al.: I.V. acetaminophen pharmacokinetics in neonates after multiple doses. Br J Anaesth. 2008; 101(4): 523-30. PubMed Abstract | Publisher Full Text

84. F Ceelie I, de Wildt SN, van Dijk M, et al.: Effect of intravenous paracetamol on postoperative morphine requirements in neonates and infants undergoing major noncardiac surgery: a randomized controlled trial. JAMA. 2013; 309(2): 149-54.

PubMed Abstract | Publisher Full Text | F1000 Recommendation 


\section{Open Peer Review}

\section{Current Peer Review Status:}

\section{Editorial Note on the Review Process}

Faculty Reviews are review articles written by the prestigious Members of Faculty Opinions. The articles are commissioned and peer reviewed before publication to ensure that the final, published version is comprehensive and accessible. The reviewers who approved the final version are listed with their names and affiliations.

\section{The reviewers who approved this article are:}

\section{Version 1}

\section{Souhayl Dahmani}

${ }^{1}$ Department of Anaesthesia, Intensive Care and Pain Management, AP-HP, Robert-Debré University Hospital, Paris, France

2 Paris Diderot University (Paris 7), Pres Paris Sorbonne Cité, Paris, France

Competing Interests: No competing interests were disclosed.

\section{Sulpicio Soriano}

${ }^{1}$ Department of Anesthesiology, Perioperative and Pain Medicine, Boston Children $\square$ s Hospital, Boston, MA, USA

2 Department of Anaesthesia, Harvard Medical School, Boston, MA, USA

Competing Interests: No competing interests were disclosed.

The benefits of publishing with F1000Research:

- Your article is published within days, with no editorial bias

- You can publish traditional articles, null/negative results, case reports, data notes and more

- The peer review process is transparent and collaborative

- Your article is indexed in PubMed after passing peer review

- Dedicated customer support at every stage

For pre-submission enquiries, contact research@f1000.com 